\title{
US PRIZES FOR IRSH ARTICLES ON LATIN AMERICA
}

Three articles on Latin American history published by the International Review of Social History have recently won US-American academic prizes.

In 1996 Norman Caulfield's "Wobblies and Mexican Workers in Mining and Petroleum, 1905-1924", in vol. 40 (1995) was given the Harvey Johnson Award for the best article published in 1995 by the Southwest Council of Latin American Studies (SCOLAS); in 1998 Caulfield's "Mexican State Development Policy and Labor Internationalism, 1945-1958”, in vol. 42 (1997) received the same SCOLAS award for the best article published in 1997 .

Erick D. Langer's "The Barriers to Proletarianization: Bolivian Mine Labour, I826I9I8", in Shahid Amin and Marcel van der Linden (eds), "Peripheral" Labour? Studies in the History of Partial Proletarianization (Cambridge [etc.], 1997) [the book edition of IRSH Supplement 4 (1996)] won the 1998 Thomas F. McGann Prize for the best article in Latin American Studies in 1997. This prize is given out by the Rocky Mountain Conference on Latin American Studies. 